\title{
Reflection on Practice Teaching Reform of College Visual Communication Design
}

\author{
Lifu Liu \\ School of Machinery and Transport \\ Southwest Forestry University \\ Kunming, Yunnan, China 650224
}

\begin{abstract}
This paper will discuss the practice teaching of visual communication design of industrial design specialty indepth based on the actual situation of visual communication design course teaching in our school and the teachers' working experience. By analyzing and reflection on the current teaching situation of visual communication design, verify the problems existing in practice teaching, and put forward effective solutions and measures against these problems. This paper will discuss the new technological means in practice teaching of visual communication design with emphasis, to cultivate students' innovative thinking and the ability of applying theoretical knowledge into practice flexibly, so as to promote the development of teaching methods and the improvement of teaching quality, and cultivate the compound talents who meet social demand better.
\end{abstract}

Keywords—visual communication design; innovative thinking; project system; industrial design

\section{INTRODUCTION}

Visual Communication Design is one of the basic disciplinary courses of industrial design specialty, mainly studies the principle and methods of visual media information communication and the way to communicate effectively. Visual Communication Design is a specialty having wide coverage of knowledge, involving visual principle, communication sciences, marketing, visual psychology and many other aspects. Therefore, from this level, Visual Communication Design not only provides theoretical support for subsequent courses of industrial design specialty, at the same time, it also has strong applicability. Visual Communication Design does not isolated in society, and it needs to connect to specific groups, market and even the entire social environment. This requires the visual communication design talents shall not only have solid theoretical foundation and skilled design skills, but also shall know about the market environment, communication technology and the development and changes of public aesthetic, especially shall have a clear sense in terms of marketing, advertising planning, brand promotion, etc, and can apply them to their design work.

The education of visual communication design specialty in China started from the 1980s. with the changes of the times, the teaching mode formed in the long-term teaching in colleges has revealed its limitations gradually, which has formed contrast with the constantly improved talent standard in the market, resulting in students having difficulties to face the fierce market competition after they have entered into the society. At present, the practice teaching of Visual Communication Design of our school mainly trains students' design skills. Because of the objective situation that school is relatively closed, training topics in the teaching process mostly adopt the virtual subjects and simulation subjects, which are unable to combine with the practical application. This makes students have difficulties to experience the design activities in real environment, and unable to verify the entire design task effectively, which is unfavorable to the cultivation of students' comprehensive quality, and there is certain gap between it and the practical work, which is not conducive to the transformation of students' knowledge. Therefore, this paper finds the problems existing in practice teaching based on the teaching experience of visual communication design course through analyzing and reflection on the current situation of visual communication design teaching, and puts forward the effective solutions and measures in combination with students' specific condition. This topic will research and explore the new technological means and cultivation mode in the practice teaching of visual communication design with emphasis, to cultivate students' innovative thinking, software application, market analysis ability and the ability of applying the knowledge that has been acquired in to real design project, so as to promote the development of teaching methods and the improvement of teaching quality, and cultivate the compound talents who meet social demand better.

\section{MAIN DIRECTION OF PRACTICAL ABILITY Cultivation}

Practical ability refers to the comprehensive ability that may solve practical problems in the daily life and work. The practical ability of students specialized in visual communication design is to use the plane visual symbols and colors as well as the professional design methods and skills to spread information, and convey concept in the plane design fields such as product packaging, advertising, printing, bookbinding, poster and corporate image, playing the role of promotion, demonstration and cognition. In essence, students' practical ability in visual communication design course not only includes the ability of acquiring new knowledge and new skills in practice activities, but also includes students' ability of applying existing knowledge and skills to practice. Here, the "practice" refers to both the broader social practice activities, 
but also refers to the narrow sense of teaching practice, professional practice, the experiment project, etc. The practical ability of students specialized in visual communication design is a kind of comprehensive ability quality formed with professional knowledge and skills as the core, living ability as the basis, and creative thinking as the key. In real environment, the key of design education lies in the cultivation of practical ability, which is mainly reflected in the following two aspects.

\section{A. Project System Teaching}

In the reform measures in visual communication design practical teaching in domestic colleges, project system teaching is a kind of common and new teaching mode. Project system teaching is a kind of "behavioral guiding" teaching form vocational promoted in Germany vocational education in the 2 st century. It is a teaching mode with "project" as the main body, guiding the professional behavior. It is a kind of student-centered teaching mode with project as the carrier to implement teaching. The most remarkable characteristic of "project system teaching" is "taking project as the main line, teacher as dominant, and students as the main body", which has changed the previous passive teaching mode of "students listen to teacher's teaching", and created the new teaching mode with students' active participation, autonomous collaboration, exploration and innovation.

With the increasingly frequent foreign exchange activities, many domestic design colleges also adopt project system teaching, which has gradually become a direction of design teaching reform. The project system teaching mode of design specialty in Chinese colleges is mainly to integrate the existing professional teachers of school according professional research direction and field, set up several studios and each of them has certain professional direction positioning, and accept the tasks according to each studio's direction and positioning. Find out the corresponding knowledge points from books according to the tasks involved in production process, so as to set up the courses related to production process as per project. Project system teaching pays more attention to students' creative participation, and teachers transform the teaching mode from focusing on teaching to focusing on improving students' vocational ability. Teachers help students to put forward subject and introduce in the actual operation project, to jointly participate in the whole process of project through analyzing and completing the project, so that the students have more opportunities to find out problems, and master the knowledge, thus to strengthen their thinking and innovation ability in learning activities.

Project system teaching is a kind of new teaching mode, having more autonomous right and a wider range of practice teaching links than the traditional teaching. This new type of project system teaching mechanism mainly is to transform the traditional closed teaching mechanism with overall arrangement and with class or specialty as the unit, into the flexible operation mechanism with studio as the basis and students can choose the development orientation independently. Various studios have the clear professional direction and project system, students can learn in the studio through twoway selection, and participate in the project practice process. But the project system teaching also has shortcomings.
Because project system teaching involves wide scope of knowledge and knowledge distribution is not balanced, the knowledge specified by syllabus cannot be covered in full in some projects, and the depth is also insufficient. So, the implementation of project system teaching also needs the supporting external environment, as it is unable to play a role in any environment. While carrying out the project system teaching, its characteristics shall be learned clearly to avoid blindly copying.

\section{B. Cultivation of Innovative Thinking}

The cultivation of innovative thinking is also the key point in the practical teaching of visual communication design in some domestic colleges. Under the circumstances of knowledge economy era, in the face of science and technology changes with each passing day and the constant replacement of peoples' aesthetic taste, the knowledge and skills that students have acquired in colleges will soon lose their effectiveness. They will be eventually eliminated from the society without the ability to keep pace with the times, self-renewal and selfimprovement. He Jie, a profession of College of Fine Arts of Tsinghua University said that: "since the 20th century, the emergence of digital media has made the social environment generate qualitative changes, and static media era can no longer meet the requirements of new century. The visual design has gradually surpassed its original category gradually, and develops toward more and more broad fields. The network technology, digital art and design, digital film and television, multimedia advertising episodes have appeared on the scene one after another. People expect visual communication design to display a magic look and meet various aspects' demand under the circumstances of unprecedented development in new spirit, new art, new tools, new space and new media." This requires the designer shall have strong innovative ability, to improve the adaptability of survival in the complex economic environment. According to the survey of Japanese "Design Art News", the quality and ability of a designer required by current market are "planning ability of design and development accounting for $30 \%$, design modeling ability accounting for $25 \%$, comprehensive thinking ability accounting for $20 \%$, organization and coordination ability accounting for $12 \%$, international feeling accounting for $8 \%$, CAD operation ability and other accounting for 5\%". We can see from the ability constitution that the abilities with high proportion all relate to innovative thinking, which also shows the importance laid on innovative talents by today's market. Art design education is not to create mechanical "operator", but to help students to understand and reconstruct themselves through practice teaching, and provide broad development space for their innovative thinking.

\section{EXPloRATION IN PRACTICE TEACHING REFORM}

Practice teaching is not only to enable students to experience the real design process, but also to cultivate students' ability of applying theoretical knowledge into practice flexibly. Practice projects are flexible and changeable, so students cannot cope with the rapid and changeable social development until they have mastered the method of linking theory with practice. As a result, school and teachers shall 
explore the new method of combining theory with practice through implementation of actual project teaching, thus to improve students' comprehensive abilities in design work.

\section{A. Optimize Classroom Teaching}

Study "project system" classroom teaching mode seriously, make efforts to cultivate students' ability of autonomous learning and cooperative learning. The following three aspects can be tried to carry out in terms of construction of new practical teaching mode: (1)Optimize teaching structure, arrange the proportion of theory teaching and practice teaching reasonably, strictly control the time that teachers impart basic knowledge, and further shorten passive teaching for students, to help realize students' feeling and experiential learning process. (2) Optimize teaching method, the more flexible and changeable teaching method shall be adopted against different teaching object and teaching content. And try to use the heuristic and interactive teaching mode to cultivate students' ability of autonomous learning and inquiry-based learning. (3) Optimize class assignment and practice, and the assignment content shall be connected with practice. At the same time, the quality, quantity and difficulty level of the assignment shall be flexible and adaptable according to different levels of each student, and to design the class assignments that are more targeted and that can stimulate students' enthusiasm and creativity.

\section{B. Improve the Practice Teaching Content}

Embedded teaching is to integrate the classroom knowledge into the practical operation of professional projects cleverly, thus to improve the teaching quality and teaching effect, which will be the new teaching mode of applied undergraduate teaching for a long time in the future. According to the requirements for teachers of visual communication design, they shall carry out the practice project, project competition and research topics that are related to the course content, to help students to effectively use various resources and methods, especially to use the Internet to obtain learning content about professional practice, to accelerate students' digest process and improve their professional skills.

\section{Update Cultivation Content Timely}

The rapid development of emerging media such as MicroBlog, WeChat and mobile client, has not only greatly changed the way of information spreading and production mode, but also has deeply changed people's ideology and way of life. Visual communication design education should conform to the trend of the times, and the cultivation of students' design skills shall be in line with the demand of new media. For instance, in application software teaching, the arrangement mode brought by software selection and new media as well as the teaching methods in terms of mobile phone interface design should be updated timely, to ensure the smooth implementation of students' practice.

In order to keep up with the development of the times and adapt to the needs of society, domestic and foreign colleges have never stopped teaching reform of visual communication design course, of which the project system teaching and innovative thinking cultivation is the relatively common research direction. To cultivate social demand-oriented applied professional design talents has become the development trend of visual communication design education. Practice teaching reform is to cultivate students' ability of applying what they have learned in class to the actual work. At the same time, create a good learning environment and real working environment for students, in order to arouse their learning enthusiasm and creativity, and strengthen students' social adaptation ability and market competitiveness. As a result, the practice teaching reform and research of Visual Communication Design is of important practical significance to the teaching development of industrial design specialty and students cultivation.

\section{REFERENCES}

[1] Song Jun. Analysis of Practice Ability Cultivation for Students Specialized in Visual Communication Design $[\mathrm{J}]$. Education and Vocation. 2015,(06)

[2] He Lei. Sun Zhiyi. Teaching Reform and Innovation of Visual Communication Design Professional Courses [J]. Journal of Hefei Normal University. Vol.33,No.1, Jan. 2015

[3] Xu Huaying. Visual Communication Design Teaching and "Studio Mode"[J]. Literature and Art Contending. 2011,(06)

[4] Wu Guixiang. New Thoughts of Visual Communication Design Teaching Reform [J]. New Visual Arts. 2010,(2)

[5] Sun Xuemei. Reflection on Visual Communication Design Teaching Reform-Combining "Project System" Teaching and Studio Teaching [J]. Science and Technology. 2014,(18)

[6] Wang Yan. New Thoughts of Visual Communication Design Teaching Design in Colleges [J]. University Education. 2014,(02) 